\title{
Purwarupa Ruang Tunggu Pintar Berbasiskan Mikrokontroler Sebagai Solusi Keamanan Siswa Setelah Pulang Sekolah
}

\section{(Microcontroller-Based Smart Waiting Room Prototype as a Security Solution for Students After Schooling)}

\author{
Deny Nusyirwan $^{1 *}$, Muhammad Abyan Fadillah ${ }^{2}$, Prasetya Perwira Putra Perdana ${ }^{3}$ \\ ${ }^{1,2,3}$ Fakultas Teknik, Program Studi Teknik Elektro, Universitas Maritim Raja Ali Haji (UMRAH) \\ ${ }^{1,2,3} \mathrm{Jl}$. Politeknik Senggarang, Tanjungpinang 29100
}

\section{ARTICLE INFO}

\section{Article history}

Received : 29 October 2020

Revised : 20 November 2020

Accepted : 24 November 2020

DOI :

http://dx.doi.org/10.33366/jast.v4i2.1786

Keywords :

Arduino;

waiting room;

school;

student.

*e-mail corresponding author :

denynusyirwan@umrah.ac.id

\section{(c) (7) (2)}

This is an open access article under the Creative Commons Attribution-ShareAlike 4.0 International License. Any further distribution of this work must maintain attribution to the author(s) and the title of the work, journal citation and DOI. CC-BY-SA

\section{ABSTRACT}

The industrial revolution 4.0 has penetrated all fields. Even now, the education sector is also one of the priority areas to improve the quality of education in schools with technological support in the world of education. From the observations, the outpouring of ideas and discussions found a significant problem in the school environment, namely the level of security and comfort of students after school hours. Problems need to be considered; It is a severe problem for students and the school in a traffic accident at a school located near the highway, kidnapping school children, and theft of valuables. Besides, this is also the comfort of students who still need to be considered after school when waiting for parents or using public transportation. Based on these problems, researchers propose a breakthrough that can be a solution and can be a benchmark and progress in the industry in education, namely a smart waiting room for school students. The technology used is the student name display system on the LCD by using RFID and Keypad input. Students in the waiting room will attach an RFID card to the RFID Reader, and then the Arduino will display a unique code on the LCD that can only be known by each parent who is waiting for his child. Also, there is a $4 \times 4$ matrix key, where each student in the smart waiting room can enter the student's parent number. If the student's number is correct then the LCD will display the student's name.

\section{PENDAHULUAN}

Berdasarkan data dari Satlantas Polres Purbalingga pada tahun 2016 mengenai kecelakaan lalulintas, diketahui bahwa kasus kecelakaan yang terjadi masih didominasi oleh kurangnya fasilitas perlengkapan bagi pengguna jalan. Oleh sebab diperlukan langkah-langkah pencegahan terhadap lokasi rawan kecelakaan [1]. Sedangkan di kabupaten Bogor, diinformasikan bahwa dari jumlah kecelakaan lalu lintas pada tahun 2016, lebih dari 50\% mengakibatkan korban jiwa [2]. Kegiatan belajar di Sekolah pada umumnya masih berlangsung pada pagi hari, siswa berangkat ke sekolah dengan mempergunakan kendaraan pribadi maupun transportasi umum. Selain dengan melengkapi fasilitas jalan terkait informasi keselamatan, Sekolah juga diperlukan untuk memberikan informasi mengenai tanda-tanda keselamatan [3]. 
Pelanggaran lalu lintas yang terjadi sering berakibat langsung terjadinya kecelakaan. Salah satu pengguna jalan adalah anak-anak. Anak-anak pada usia dini, lebih banyak menghabiskan waktu di rumah dan sekolah. Peran orang tua dan guru diperlukan untuk menumbuhkan kesadaran keselamatan di jalan. [4]

Lingkungan sekolah merupakan tempat para siswa dan siswi mencari ilmu dan menemukan hal-hal baru untuk dipelajari. Disaat ini banyak sekolah yang tidak memiliki fasilitas yang memadai baik dalam hal menunjang baiknya pembelajaran, kedisiplinan/kefektifan, maupun keamanan. Dalam hal ini masih banyak sekolah yang tidak peduli pada keamanan para siswanya saat setelah pulang sekolah, sebagai contoh para siswa seringkali dibiarkan berkeliaran di luar pagar sekolah tanpa pengawasan dan pengamanan.

Pengawasan dan pengamanan yang semakin melemah ini menjadikan lingkungan sekolah mejadi tempat yang rentan akan terjadinya kegiatan kriminal dan baik penculikan ataupun perusakan maupun tempat yang rentan akan terjadinya kecelakaan apabila sekolah tersebut terletak dekat dengan jalan raya. Meningkatnya kejadian kriminal dan kecelakaan yang terjadi pada anak saat di lingkungan sekolah merupakan dampak asli dari kurangnya pengawasan dan pengamanan di lingkungan sekolah pada saat ini.

Dari hasil observasi, curahan gagasan dan diskusi maka ditemukan sebuah permasalahan utama di lingkungan sekolah yaitu tingkat keamanan siswa setelah selesai jam pelajaran di sekolah. Selain hal keamanan, kenyamanan siswa yang masih perlu diperhatikan setelah selesai pelajaran ketika menunggu penjemputan dari orang tua atau menggunakan transportasi umum. Berdasarkan permasalahan tersebut, peneliti mengusulkan sebuah terobosan yang dapat menjadi solusi sekaligus dapat menjadi tolak ukur dan kemajuan bidang industri di dalam dunia pendidikan, yaitu ruang tunggu pintar untuk siswa sekolah. Teknologi yang dipergunakan berbasiskan mikrokontroler arduino uno dan sistem penampilan nama siswa pada LCD dengan menggunakan input dari RFID dan Keypad. Siswa yang berada pada ruang tunggu akan menempelkan kartu RFID pada RFID Reader, maka Arduino akan menampilkan sebuah kode unik pada LCD yang hanya dapat diketahui oleh masingmasing orang tua yang sedang menunggu anaknya. Selain itu terdapat matrix key $4 \times 4$, dimana setiap siswa sekolah yang berada di ruang tunggu pintar dapat di masukkan nomor induk siswa, apabila nomor induk siswa tersebut benar maka pada LCD akan menampilkan nama dari siswa tersebut.

\section{METODE KEGIATAN}

Desainer memainkan peran strategis dalam inovasi dan proses transisi menuju masyarakat yang berkelanjutan. Desainer bertindak di semua lapisan masyarakat dan membutuhkan bantuan untuk menemukan jalan melalui sistem inovasi yang semakin saling terkait [5],

Dengan Design Thinking maka pemahaman kebutuhan pelanggan dilakukan dengan mempertimbangkan apa yang layak secara teknis dan ekonomis nantinya [6]. 


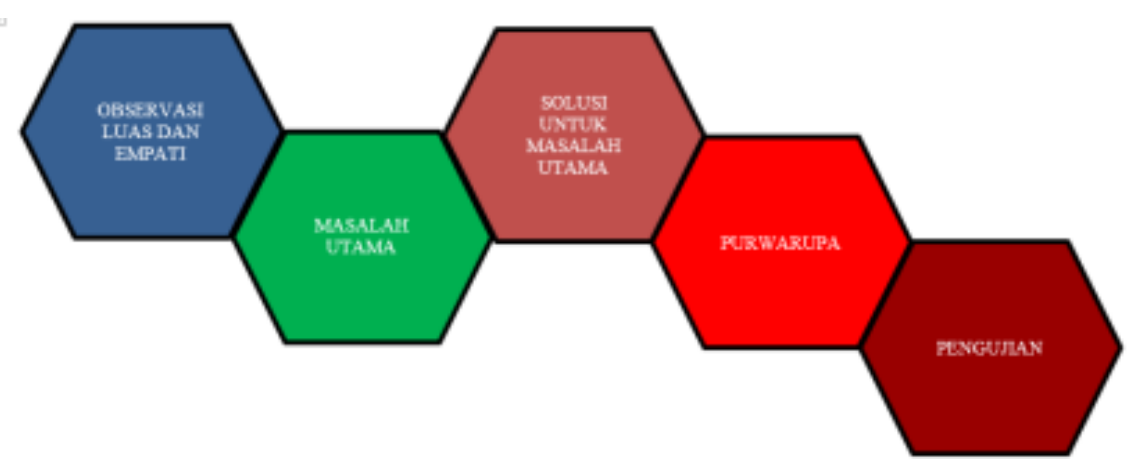

Gambar 1. Tahapan pada Proses Desain Rekayasa Stanford Design School dengan pendekatan Design Thinking [7]

Penelitian dimulai dengan pendekatan Design Thinking yang diperkenalkan oleh Stanford Design School. lihat Gambar 1. Proses ini memiliki 5 tahapan, pada tahapan awal dimulai dengan empati sebagai modal dasar dalam pelaksanaan observasi secara luas di masyarakat. Dalam tahapan ini peneliti berusaha untuk mampu mengalami emosi dan mengetahui apa yang dipikirkan oleh calon pengguna.

Tahapan kedua adalah melakukan pemilihan permasalahan utama, tahapan ketiga adalah mengembangkan ide-ide sebagai solusi terhadap permasalahan utama untuk mendapatkan solusi utama sehingga dapat dilanjutkan ke tahapan pembuatan purwarupa dengan memperhatikan bahwa purwarupa yang dihasilkan sederhana dan mudah dirubah. Tahapan terahir adalah pengujian, bertujuan untuk mengetahui kinerja dari purwarupa dan mendapatkan masukan untuk perbaikan inovasi.

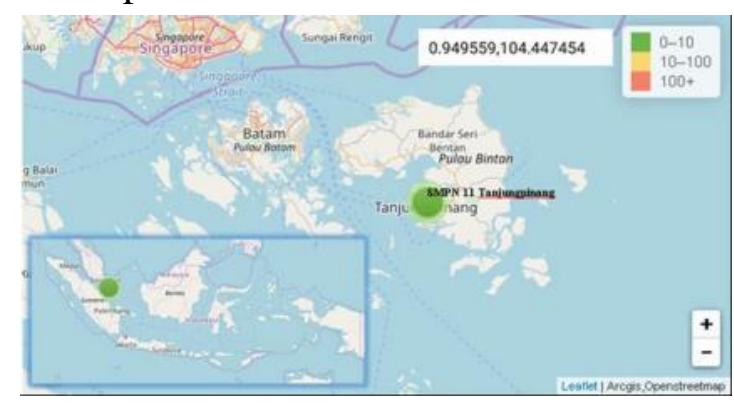

Gambar 2. Lokasi SMPN 11 Tanjungpinang [8]
Adapun metode observasi yang dipergunakan adalah metode observasi Peserta sebagai peneliti. Dengan metode ini maka peneliti dan kelompok yang diteliti akan lebih lebih dekat dan terbuka sehingga timbul saling percayaan, pada ahirnya akan memberikan informasi yang lebih dalam [9]. Lokasi penelitian dilakukan di SMPN 11 Tanjungpinang, Kepulauan Riau, lihat Gambar 2.

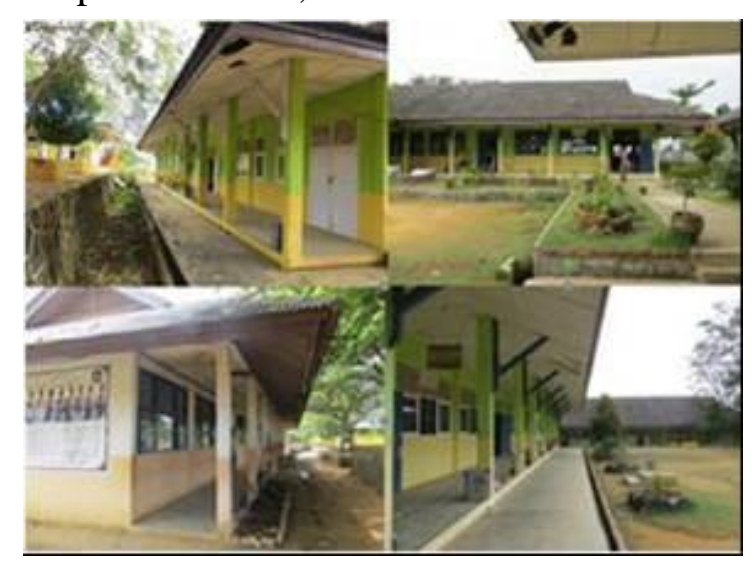

Gambar 3. Suasana di SMPN 11 Tanjungpinang [10]

Sedangkan Gambar 3 menampilkan keadaaan di SMPN 11 Tanjungpinang.

Pada Gambar 4 memperlihatkan peneliti melakukan proses pengumpulan informasi di SMPN 11 Tanjung pinang . 


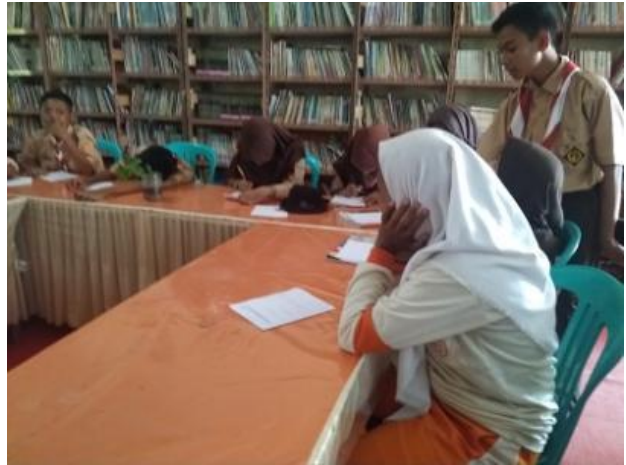

Gambar 4. Mengumpulkan informasi mengenai permasalahan yang terdapat di sekolah melalui siswa

Curahan gagasan adalah metode individu atau kelompok untuk menghasilkan ide dan meningkatkan kreatifas [11].. Pada Gambar 5 menampilkan proses pengumpulan masalah yang ditemukan ketika observasi.

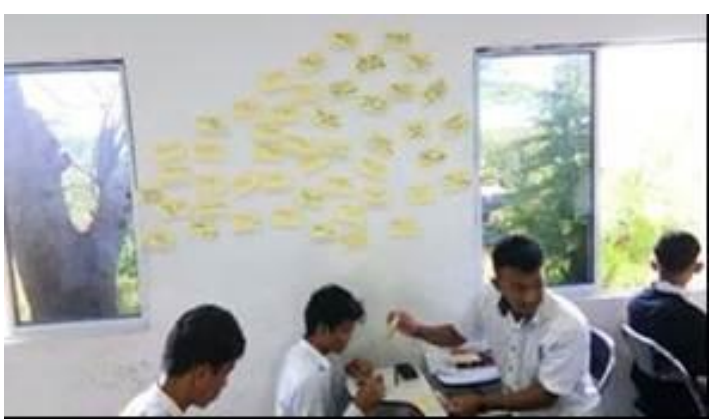

Gambar 5. Proses pengumpulan masalah

Sedangkan pada Gambar 6. menampilkan prosesn penentuan masalah utama, yaitu adalah kemanan dan kenyamanan siswa setelah pulang sekolah

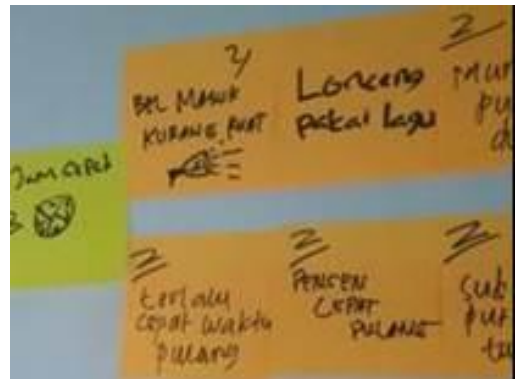

Gambar 6. Proses pengerucutan masalah untuk mendapatkan masalah utama
Solusi utama yang diusulkan ditampilkan dengan menggunakan bahan-bahan yang ekonomis, bertujuan untuk memudahkan desainer melakukan perubahan. Sila lihat pada Gambar 7

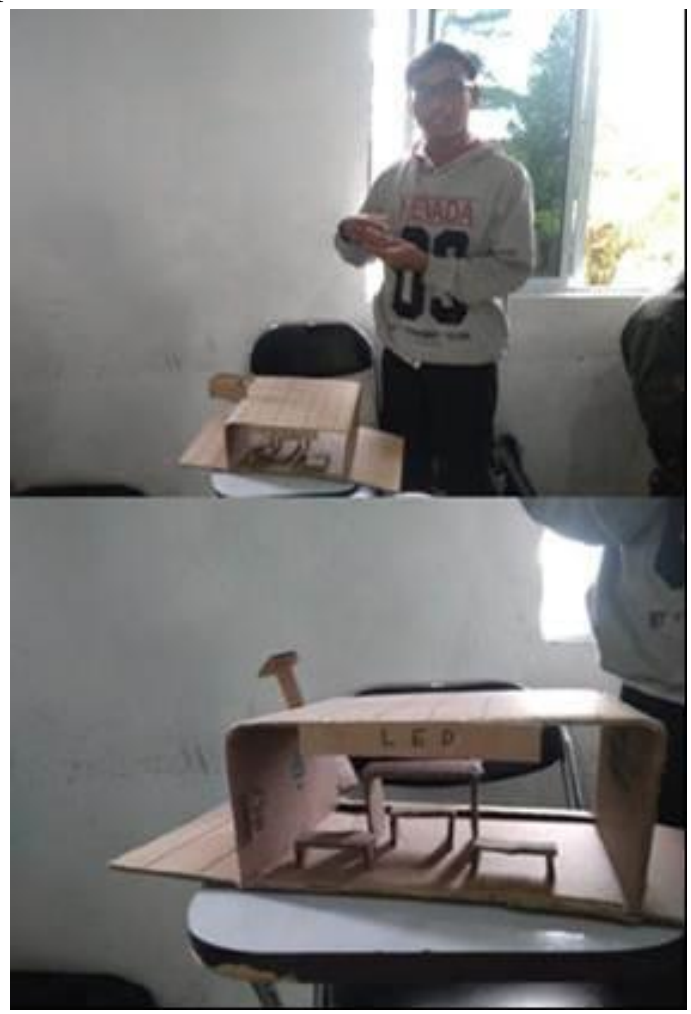

Gambar 7. Konsep solusi

\section{KARYA UTAMA}

\subsection{Purwarupa}

Sebuah purwarupa sederhana dari ruang tunggu yang sudah di integrasikan dengan mikrokontroler arduino uno dapat dilihat pada Gambar 8.

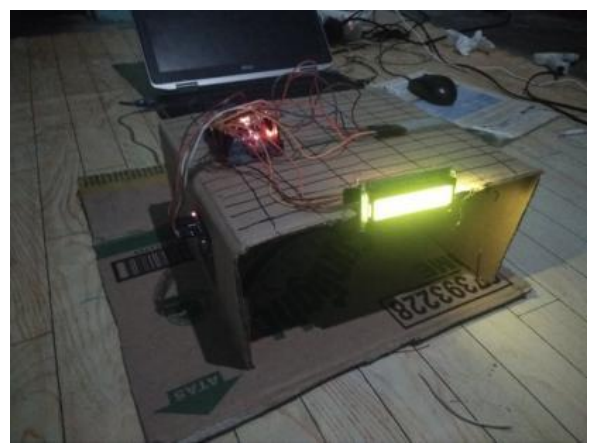

Gambar 8. Purwarupa Sederhana 
Purwarupa ruang tunggu pintar menggunakan beberapa komponen mikrokontroler sebagai berikut diantaranya: Arduino Uno, MFRC-522, Matrix key $4 \times 4$, dan LCD dengan backpack I2C. prototype ini berkerja dengan cara menampilkan suatu text di lcd dan melakukan hitung mundur pemanggilan dengan suatu audio yang telah disiapkan dalam DF Mini Player.

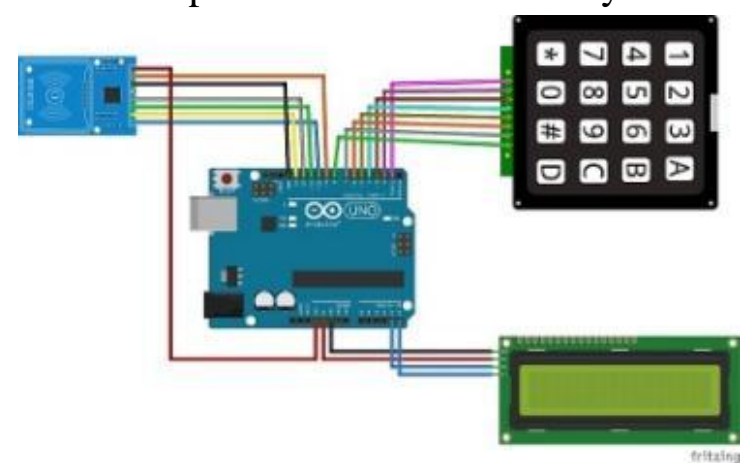

Gambar 9. Rangkaian elektronika sistem ruang tunggu pintar

Pada Gambar 9 menampilkan Rangkaian elektronika sistem ruang tunggu pintar. Dalam pengerjaan purwarupa ini maka dibuatlah satu fungsi yaitu print text pada LCD setelah mendapatkan aksi perintah pada matrix key atau pada MFRC-522. Sebagai contoh seorang siswa akan membawa sebuah kartu RFID yang telah diprogram kedalam arduino uno, setelah itu apabila siswa itu hendak akan ingin pulang maka siswa tersebut akan menempelkan kartu tersebut pada sensor MFRC-522 maka pada LCD akan menampilkan sebuah kode unik. Kode unik siswa tersebut dapat diketahui oleh masing-masing orang tua terhadap anaknya untuk dapat mengenali bahwa anaknya sedang dalam halte pintar yang apabila anaknya ingin dijemput maka orang tua dapat melakukan verifikasi terhadap keaslian hubungan darah keduanya pada halte tersebut. Selain itu terdapat matrix key $4 \times 4$ yang memiliki fungsi dengan MFRC-522 yaitu sebagai pemicu aksi terhadap tindakan pengguna untuk menampilkan print text pada lcd, namun yang berbeda pada matrix key $4 \times 4$ ini aksi yang diberikan berupa pin (Nomor Induk Siswa) yang dimiliki oleh setiap siswa di sekolah lalu dapat di masukkan atau di tekan pada pin matrix key $4 \times 4$. Apabila nomor induk siswa tersebut benar maka pada lcd akan menampilkan nama dari siswa tersebut.

\subsection{Komponen purwarupa}

Adapun komponen yang diperlukan untuk pembuatan purwarupa dengan estimasi harga dapat dilihat pada Tabel 1.

Tabel 1. Estimasi anggaran (Bukalapak, diakses 1 Maret 2020)

\begin{tabular}{llccc}
\hline No. & Barang & Jumlah & $\begin{array}{c}\text { Harga } \\
\text { Satuan (Rp) }\end{array}$ & $\begin{array}{c}\text { Harga } \\
\text { Total (Rp) }\end{array}$ \\
\hline 1 & Arduino Uno & 1 & 48000 & 48000 \\
\hline 2 & Keypad 4x4 & 1 & 15000 & 15000 \\
\hline 3 & $\begin{array}{l}\text { RFID Reader } \\
\text { dan Tag }\end{array}$ & 1 & 25000 & 25000 \\
\hline 4 & Kabel Jumper & 20 & 1000 & 20000 \\
\hline 5 & $\begin{array}{l}\text { LCD dan } \\
\text { I2C }\end{array}$ & 1 & 24000 & 24000 \\
\hline & Jumlah & & & 132000 \\
\hline
\end{tabular}

\subsubsection{Arduino UNO R3}

Arduino Uno R3 di Gambar 10 adalah sebuah mikrokontroler yang mengolah data-data yang didapatkan dari RFID selanjutnya ditampilkan pada layar LCD.

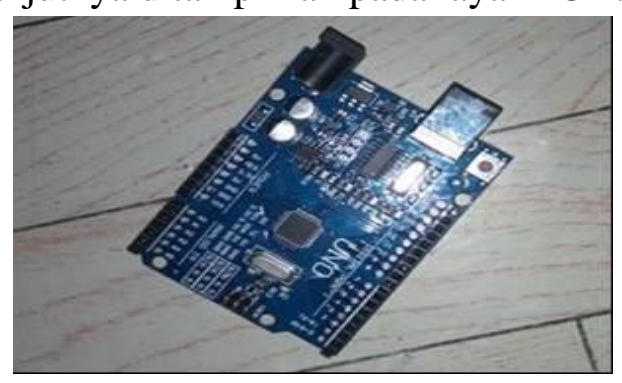

Gambar 10. Arduino Uno 


\subsubsection{Kabel jumper}

Komponen yang dipergunakan di tancapkan pada Breadboard. Untuk menghubungkan komponen-komponen tersebut diperlukan penghubung yang berupa kabel, sila lihat Gambar 11.

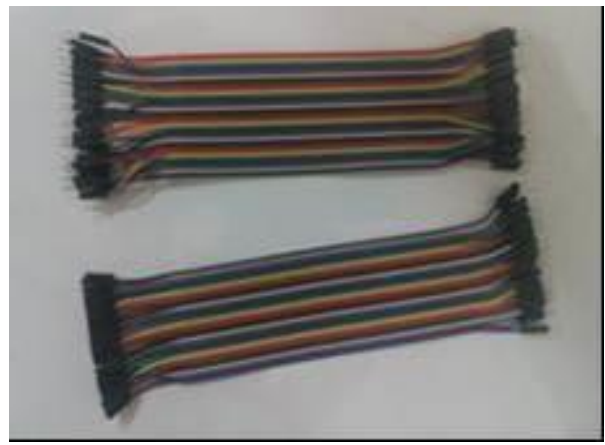

Gambar 11. Kabel Jumper

\subsubsection{RFID}

RFID atau dikenal dengan istilah Radio Frequency Identification, mempergunakan frekuensi radio untuk proses identifikasi. Adapun perangkat RFID yang dipergunakan terdiri dari Card Tag dan RFID reader, lihat Gambar 12.

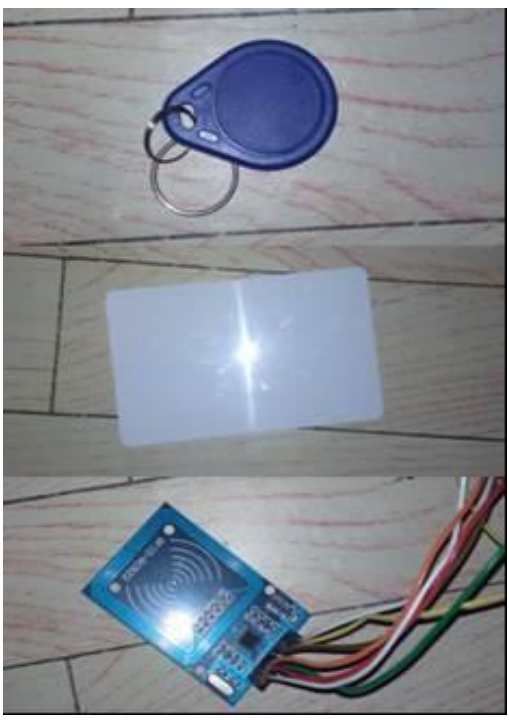

Gambar 12 RFID RC522 Reader dan Card Tag RFID Pasif

\subsubsection{LCD}

LCD (Liquid Cristal Display) merupakan layar yang menampilkan teks yang dihasilkan dari proses minkrokontroller sebagai informasi kepada pengguna untuk mengetahui status alat yang sedang beroperasi. Sila lihat Gambar 13.

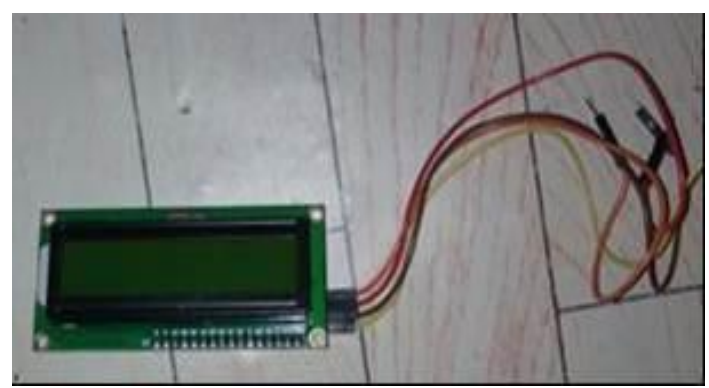

Gambar 13. Liquid Cristal Display

\subsubsection{I2C Serial}

Jumlah pin yang terdapat pada Arduno terbatas dan proses penyolderan terkadang dapat menyebabkan LCD menjadi panas dan rusak. Untuk menghindari hal tersebut, maka diperlukan I2C (Inter Integratred Circuit).. Sila lihat Gambar 14

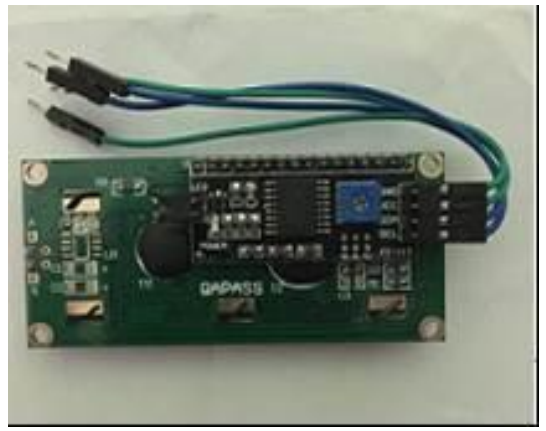

Gambar 14. I2C

\subsubsection{Keypad}

Perintah external kepada program yang sudah disusun, diberikan melalui keypad. Keypad adalah bentuk sederhana dari keyboard yang pada umumnya 
dipergunakan. Terdiri dari angka dan huruf. Sila lihat Gambar 15.

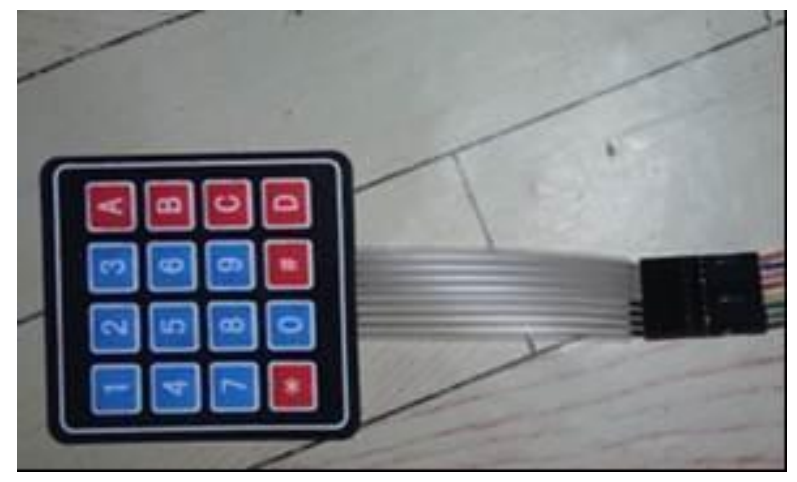

Gambar 15. Keypad 4x4

\subsection{Program pada Arduino}

Pada Gambar 16 menampilkan skematik diagram dari ruang tungg yang akan dipergunakan sebagai referensi untuk menyusun program dengan luaran yang di inginkan.

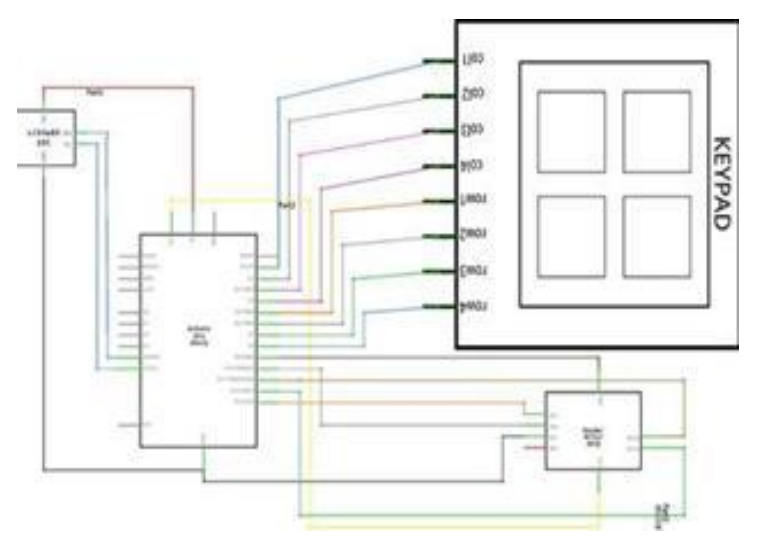

Gambar 16. Skematik diagram dari ruang tunggu berbasiskan Arduino Uno

Dapat dilihat pada sketch program diatas didalam prototype ini menggunakan module RFID dan LCD I2C. jika menggunakan I2C maka kita harus mengetahui alamat I2C yang kita gunakan, karena jika tidak maka LCD tidak dapat digunakan dan eror saat di program. Sila lihat Gambar 17.

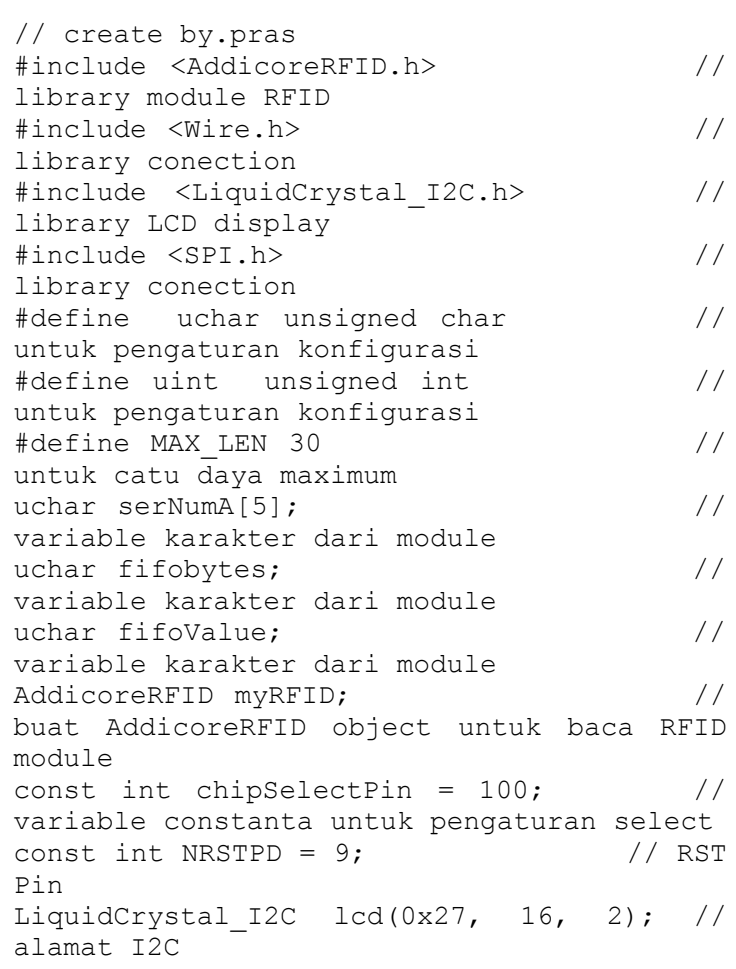

Gambar 17. input library dan inisilisasi

Di dalam void setup kita atur input dan outputnya, pada kondisi prototype ini yang sebagai input adalah modul RFID dan outputnya adalah LCD display. Cara kerja nya mudah cukup dengan menampilkan card tag RFID di module RFID maka LCD display akan menmapilkan text monitor yang sudah di sett di dalam program. Serial komunikasi yang digunakan 9600 baud dan dengan delay $500 \mathrm{~ms}$ satuan microsecond. lihat Gambar 18.

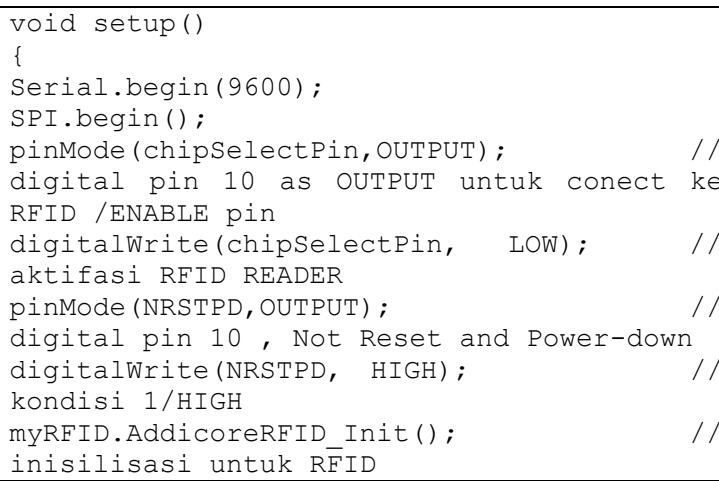




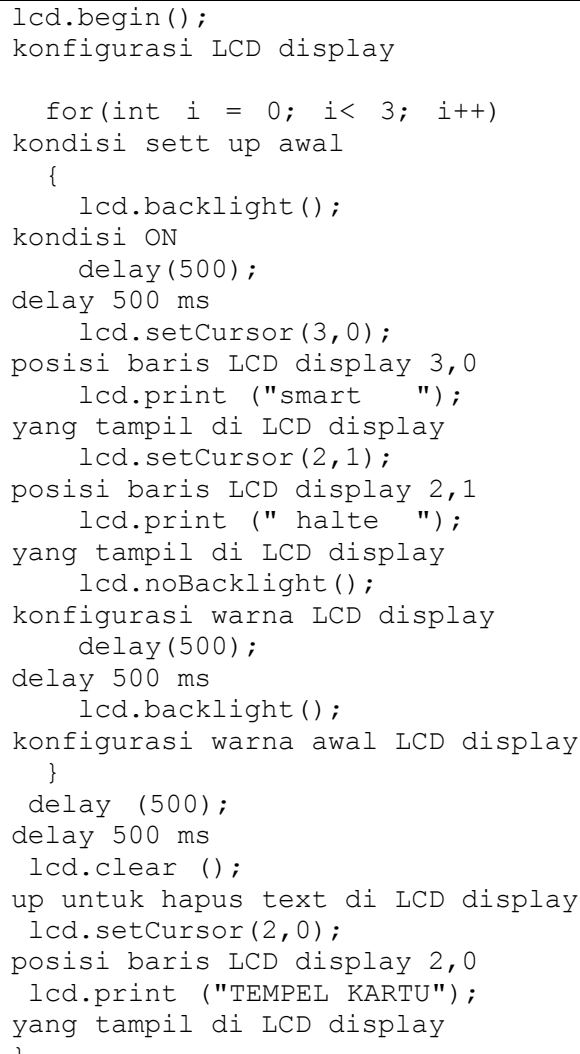

Gambar 18. void setup mengatur input dan output

Setalah mengatur void setup maka selanjut adalah mengatur void loop atau fungsi perulangan yang akan dibaca oleh program. Pada sketch program ini yang di atur adalah pada saat pergantian kartu maka serial monitor dan LCD display akan menampilakn masing masing text yang berbeda. Jika menggunakan module RFID dan di tag dengan 4 buah kartu maka langkah nya kita harus tau dulu nomor card tag yang bagian terakhir pada card tag tersebut dan setelah itu 3 digit terakhir dari card tag digunakan untuk inisialisasi dan konfigurasi pada pembacaan kartu. lihat Gambar 19.

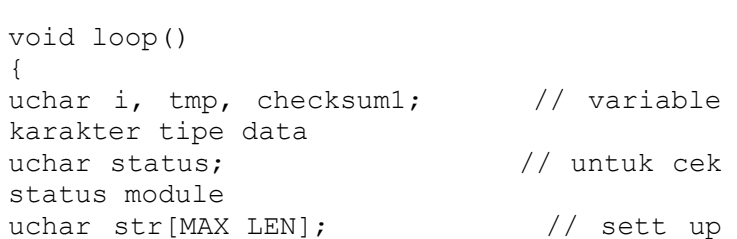




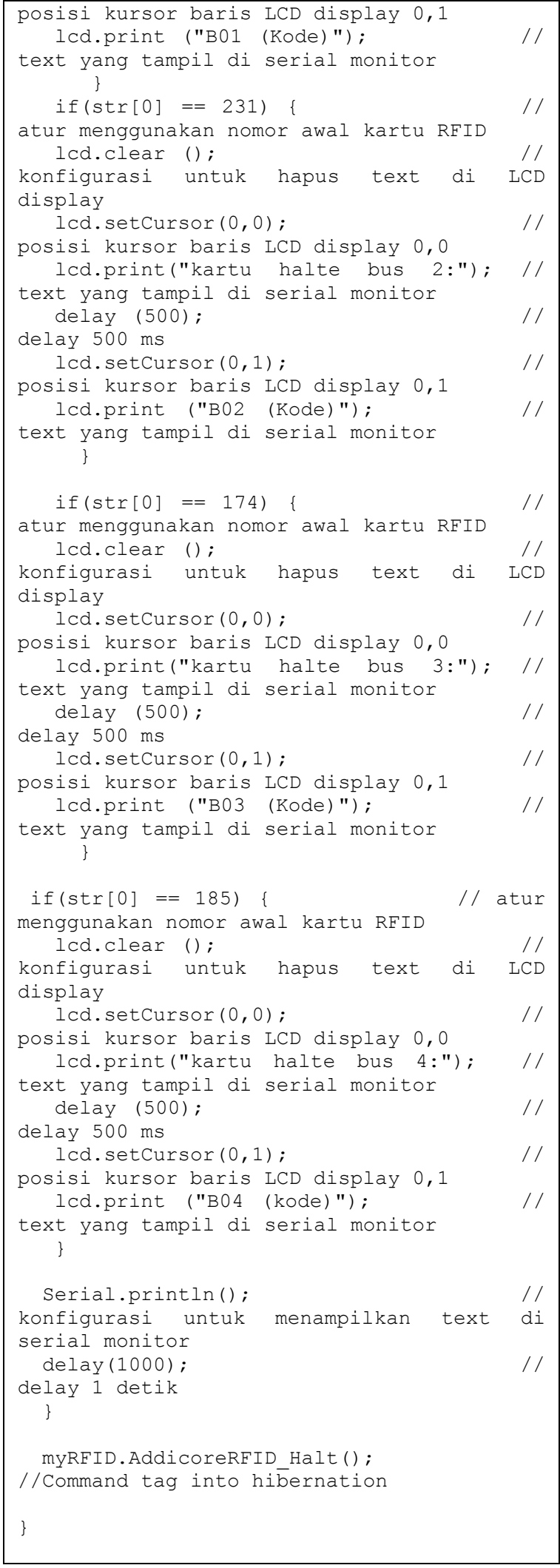

Gambar 19. void loop mengatur fungsi perulangan

\section{ULASAN KARYA}

Pada purwarupa menggunakan modul RFID mfrc-522 yaitu modul RFID (radio frequency identification), sesuai spesifikasi komponen ada 2 model kartu yang dapat dipergunakan dalam modul RFID yaitu keycard dan ID card, oleh karena itu dilakukan pengujian terhadap kedua kartu tersebut untuk mengetahui ketahanan kartu, benda apa saja yang dapat menghalang akses kartu, serta jarak kartu dapat bekerja.

Dari beberapa pengujian, ditemukan eror atau akses yang tidak terdeteksi yaitu pada saat card tag RFID di lapis dengan benda berupa telepopn seluler dengan ketebalan $0,5 \mathrm{~cm}$ ditempelkan pada modul RFID. Dan setelah itu kami melakukan pengujian yang kedua mengguanakan key card dan hasilnya dapat di lihat pada tabel, Pada saat key card di lapis dengan telepon seluler setebal $0,5 \mathrm{~cm}$ dan di tempelkan pada modul RFID, diketahui kartu tidak terdeteksi dan purwarupa tidak bekerja. Untuk hasil pengujian Card Tag dapat dilihat pada Tabel 2 dan hasil pengujian Key Card dapat dilihat pada Tabel 3.

Tabel 2. Hasil Pengujian Card Tag

\begin{tabular}{|l|l|l|}
\hline Jenis kartu & $\begin{array}{l}\text { Benda / objek lapisan } \\
\text { kartu RFID }\end{array}$ & Defect / kondisi \\
\hline Card tag ID & Kertas & $\begin{array}{l}\text { Kartu terdeteksi } \\
\text { dan purwarupa } \\
\text { bekerja }\end{array}$ \\
\hline Card tag ID & Buku tebal $0,5 \mathrm{~cm}$ & $\begin{array}{l}\text { Kartu terdeteksi } \\
\text { dan purwarupa } \\
\text { bekerja }\end{array}$ \\
\hline Card tag ID & $\begin{array}{l}\text { Benda plastic tebal } \\
0,1 \mathrm{~cm}\end{array}$ & $\begin{array}{l}\text { Kartu terdeteksi } \\
\text { dan purwarupa } \\
\text { bekerja }\end{array}$ \\
\hline Card tag ID & Gabus tebal $0,8 \mathrm{~cm}$ & $\begin{array}{l}\text { Kartu terdeteksi } \\
\text { dan purwarupa } \\
\text { bekerja }\end{array}$ \\
\hline Card tag ID & Handphone tebal $0,5 \mathrm{~cm}$ & $\begin{array}{l}\text { Kartu tidak } \\
\text { terdeteksi dan } \\
\text { purwarupa tidak } \\
\text { bekerja }\end{array}$ \\
\hline
\end{tabular}


Tabel 3. Hasil Pengujian Key Card

\begin{tabular}{|l|l|l|}
\hline Jenis kartu & $\begin{array}{c}\text { Benda / objek lapisan } \\
\text { kartu RFID }\end{array}$ & Defect / kondisi \\
\hline $\begin{array}{l}\text { Key card } \\
\text { RFID }\end{array}$ & Kertas & $\begin{array}{l}\text { Kartu terdeteksi } \\
\text { dan prototype } \\
\text { bekerja }\end{array}$ \\
\hline $\begin{array}{l}\text { Key card } \\
\text { RFID }\end{array}$ & Buku tebal $0,5 \mathrm{~cm}$ & $\begin{array}{l}\text { Kartu terdeteksi } \\
\text { dan prototype } \\
\text { bekerja }\end{array}$ \\
\hline $\begin{array}{l}\text { Key card } \\
\text { RFID }\end{array}$ & $\begin{array}{l}\text { Benda plastic tebal } \\
0,1 \mathrm{~cm}\end{array}$ & $\begin{array}{l}\text { Kartu terdeteksi } \\
\text { dan prototype } \\
\text { bekerja }\end{array}$ \\
\hline $\begin{array}{l}\text { Key card } \\
\text { RFID }\end{array}$ & Gabus tebal $0,8 \mathrm{~cm}$ & $\begin{array}{l}\text { Kartu terdeteksi } \\
\text { dan prototype } \\
\text { bekerja }\end{array}$ \\
\hline $\begin{array}{l}\text { Key card } \\
\text { RFID }\end{array}$ & Handphone tebal $0,5 \mathrm{~cm}$ & $\begin{array}{l}\text { Kartu tidak } \\
\text { terdeteksi dan } \\
\text { prototype tidak } \\
\text { bekerja }\end{array}$ \\
\hline
\end{tabular}

\subsection{Pengujjian pengalaman pengguna}

Pengalaman pengguna akan memperluas pandangan tentang interaksi produk dengan pengguna dari aspek emosional. Adapun motivasi dari proses pengalaman pengguna adalah untuk mengembangkan pengalaman dan emosi positif. Oleh karena itu, produk harus memenuhi kebutuhan psikologis dan motif pelanggan [12]. Sila lihat Gambar 20.

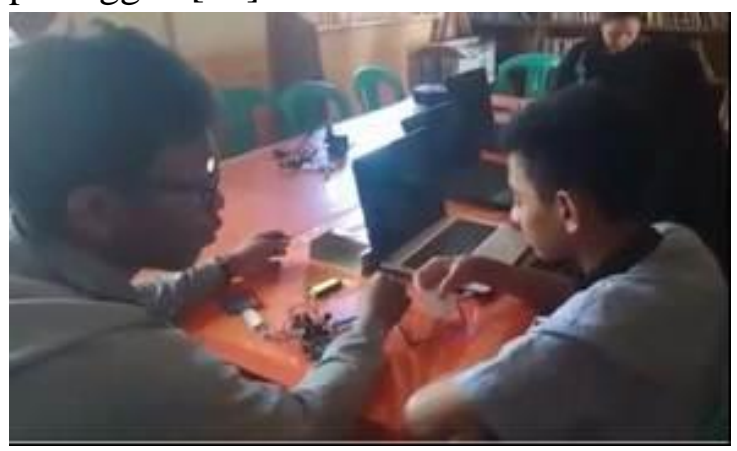

Gambar 20. Pengujian kegunaan

\section{DAMPAK \& MANFAAT KegiataN}

Pendekatan desain tradisional telah dituduh gagal untuk terlibat dengan pengguna dalam proses perancangan untuk mendapatkan kompromi peluang komersial dan pengalaman interaksi pengguna. Sebagai alternatif lain, pendekatan partisipatif didalam proses perancangan diterapkan dalam menghasilkan ide untuk mendapatkan peluang produk baru [13], pendekatan partisipatif pengguna adalah pendekatan perancngan yang mengundang pemangku kepentingan ke dalam proses desain sebagai cara untuk memahami dan bertemu untuk mengetahui lebih awal kebutuhan mereka [14].

Pada Gambar 16 menampilkan proses perancangan yang bresifat partisipatif berupa pengujian purwarupa. Perancangan dengan partisipatif muncul sekitar 25 tahun yang lalu sebagai seperangkat praktik desain dan penelitian yang berbeda yang berakar pada pendekatan Skandinavia untuk desain sistem, yang biasanya digolongkan di bawah label 'desain kooperatif', yang menekankan para desainer dan pengguna secara aktif bekerja bersama dalam suatu proses bertujuan meningkatkan kualitas kehidupan kerja [15]. Dalam situasi desain partisipatif, kompetensi fasilitator akan memengaruhi peluang bagi kelompok pengguna untuk terlibat dalam proses desain [16]. Pada Tabel 4 menampilkan hasil interview dengan calon pengguna. Dapat dilihat bahwa inovasi yang dihasilkan bermanfaat bagi sekolah. Purwarupa yang dihasilkan mudah dipergunakan oleh calon pengguna. dan teknologi mikrokontroller mampu menarik minat siswa. Inovasi dapat berfungsi dengan baik dan sudah optimal untuk menjadi landasan pengembangan selanjutnya. 
Tabel 4. Hasil Interview dari calon pengguna

\begin{tabular}{|c|c|c|c|c|c|c|c|c|c|}
\hline \multirow{3}{*}{ No. } & \multirow{3}{*}{ PERTANYAAN } & \multicolumn{4}{|c|}{ CALON PENGGUNA PERTAMA } & \multicolumn{4}{|c|}{ CALON PENGGUNA KEDUA } \\
\hline & & 4 & 3 & 2 & 1 & 4 & 3 & 2 & 1 \\
\hline & & $\underset{\text { BAIK }}{\text { SANGAT }}$ & BAIK & CUKUP & KURANG & $\begin{array}{l}\text { SANGAT } \\
\text { BAIK }\end{array}$ & BAIK & CUKUP & KURANG \\
\hline 1 & $\begin{array}{l}\text { PURWARUPA INI } \\
\text { MUDAH DIGUNAKAN }\end{array}$ & & & & & & & & \\
\hline 2 & INOVASI MENARIK & & & & & & & & \\
\hline 3 & $\begin{array}{l}\text { INOVASI BERGUNA } \\
\text { UNTUK } \\
\text { MASYARAKAT }\end{array}$ & & & & & & & & \\
\hline 4 & $\begin{array}{l}\text { INOVASI DAPAT } \\
\text { BERFUNGSI }\end{array}$ & & & & & & & & \\
\hline 5 & $\begin{array}{l}\text { SISTEM SUDAH } \\
\text { OPTIMAL }\end{array}$ & & & & & & & & \\
\hline
\end{tabular}

\section{KESIMPULAN}

Kegiatan ini merupakan sebuah terobosan dalam dunia pendidikan sebagai suatu tolak ukur bahwasanya fasilitas yang ada di lingkungan sekolah juga sudah maju sesuai dengan revolusi industri 4.0. Dari hasil pengujian kegunaan didapatkan bahwa teknologi yang dihasilkan adalah sebuah solusi untuk meningkatkan keamanan dan kenyaman siswa sesuai masalah yang diangkat pada karya ini. Ruang tunggu pintar ini juga dapat menjadi sebuah ide bisnis industri jasa sebagai penyedia halte pintar dan nyaman di tahun-tahun mendatang.

Selanjutnya dalam pengembangan purwarupa yang telah dibuat pada karya ini, dapat langsung diterapkan atau diaplikasikan alat-alat pendukung pada ruang tunggu pintar ini di sebuah ruang tunggu biasa. halte biasa dapat dijadikan sebagai acuan sebelum dirancang ruang tunggu sesungguhnya.

\section{PENGHARGAAN}

Terima kasih kepada civitas akademika di jurusan teknik elektro Universitas Maritim Raja Ali Haji (UMRAH).

\section{DAFTAR PUSTAKA}

[1] Ermawati A D, Sugiyanto G, and Indriyati, E, W, Penentuan Lokasi Rawan Kecelakaan Lalu Lintas dengan Pendekatan Fasilitas Perlengkapan Jalan di Kabupaten Purbalingga, Jurnal Dinamika Rekayasa, 2019, 15(1) : 65-74

[2] Astarina L, Sugiyanto G, and Indriyati E W, Karakteristik Kecelakaan Lalu Lintas dan Analisis Lokasi Black Spot di Kabupaten Bogor, Jurnal Dinamika Rekayasa, 2018, 14(2) : 65-76

[3] Saleh A, Soehardi F, and Anggraini M, Implementasi Keselamatan Lalu Lintas Untuk Anak Sekolah Dasar Yang Berada Di Pinggir Jalan Lintas Barat, Jurnal Dinamisia, 2017, 1(1) : 35-38 
[4] Wijana N and Sanusi M, Sosialisasi Keselamatan Dan Kesehatan Kerja Sekolah Di Sekolah Dasar Gugus I Dan Ii Kecamatan Sawan Kabupaten Buleleng, Widya Laksana, 2014, 3(2) : 63-69

[5] Joore P, and Brezet H, A Multilevel Design Model: The Mutual Relationship Between ProductService System Development And Societal Change Processes, Journal of Cleaner Production, 2015, 97 : 92-105

[6] Pereira J C, and Russo R F S M, Design Thinking Integrated in Agile Software Development: A Systematic Literature Review, Procedia Computer Science, 2018, $138: 775-782$

[7] What is Design Thinking? [Daring], Tersedia pada https://www.enterpriseirregulars.co m/125085/what-is-design-thinking/ [ Diakses : 3 Agustus 2019 ].

[8] Sekolah Kita SMP NEGERI 11 TANJUNGPINANG [Daring], Tersedia pada : http://sekolah.data.kemdikbud.go.id/ index.php/chome/profil/007328BD31F5-E011-BF42-F542CFCD811C [ Diakses : 31 Mei 2019].

[9] Wagner C, Kawulich B, and Garner M, Collecting Data Through Observation, Doing Social Research: A global context, 2012

[10] Sekolah Kita SMP NEGERI 11 TANJUNGPINANG [Daring], Tersedia pada http://sekolah.data.kemdikbud.go.id/ index.php/chome/profil/007328BD31F5-E011-BF42-F542CFCD811C [ Diakses : 31 Mei 2019 ].
[11] Zainol A S, Wan Mohd Yusof W Z, Mastor K A, Sanusi Z M, and Ramlie N M, Using Group Brainstorming in Industrial Design Context: Factors Inhibit and Exhibit, Procedia - Social and Behavioral Sciences, 2012, 49 : 106-119

[12] von Saucken C, Lachner F, and Lindemann U, Principles for User Experience What We Can Learn from Bad Examples, International Conference on Kansei Engineering \& Emotion Research, 2014

[13] Wilkinson C R, and De Angeli A, Applying user centred and participatory design approaches to commercial product development, Design Studies, 2014, 35 (6) : 614631

[14] UX Magazine, Participatory Design in Practice, https://uxmag.com/articles/participat ory-design-in-practice

[15] Halskov K, and Hansen N B, The diversity of participatory design research practice at PDC 20022012, International Journal of Human-Computer Studies, 2015, $74: 81-92$

[16] Kang M, Choo P, and Watters C E, Design for Experiencing: Participatory Design Approach with Multidisciplinary Perspectives, Procedia - Social and Behavioral Sciences, 2015, 174 : 830-833 